\title{
Tetrachlorodibenzo-p-dioxin Alters Rat Hypothalamic Endorphin and Mu Opioid Receptors
}

\author{
LORELLE L. BESTERVELT, ${ }^{*} \ddagger$ COLLEEN J. NOLAN,* $\ddagger$ YONG CAI,* PHAITOON MAIMANSOMSUK,* \\ CAROL A. MOUSIGIAN* AND WALTER N. PIPER* $\ddagger^{*}$
}

*Toxicology Program, School of Public Health, +Department of Pharmacology, Medical School and $\ddagger$ Reproductive Sciences Program, The University of Michigan, Ann Arbor, MI 48109-2029

Received 29 April 1991

\begin{abstract}
BESTERVELT, L. L., C. J. NOLAN, Y. CAI, P. MAIMANSOMSUK, C. A. MOUSIGIAN AND W. N. PIPER. Tetrachlorodibenzo-p-dioxin alters rat hypothalamic endorphin and mu opioid receptors. NEUROTOXICOL TERATOL 13(5) 495-497, 1991. - The present study was undertaken to assess if hypothalamic $\beta$-endorphin $(\beta E)$ and/or brain mu opioid receptors are associated with 2, 3, 7, 8-tetrachlorodibenzo-p-dioxin (TCDD) $(50 \mu \mathrm{g} / \mathrm{kg}$ )-induced hypophagia and body weight decline in rats. Hypothalamic BE concentrations were initially increased to $166 \%$ of controls on day 1 , and then were depressed to $39 \%$ and $49 \%$ of control values on days 2 and 3, respectively. Brain mu opioid receptor number was increased $60 \%$ in TCDD-treated rats at day 3 without a change in the binding affinity. Food-restricted rats did not exhibit changes in hypothalamic $\beta E$ concentrations or brain mu opioid receptor number. These results indicate that TCDD causes early perturbations in hypothalamic $\beta E$ concentrations and brain mu receptor number, which may contribute to the mechanisms by which TCDD leads to decreased food intake and progressive weight loss.
\end{abstract}

2, 3, 7, 8-Tetrachlorodibenzo-p-dioxin Hypothalamic $\beta$-endorphin Brain mu opioid receptor Food intake

TCDD is an undesired by-product produced during the synthesis of various chlorinated phenolic compounds, incineration of waste, and bleaching of paper pulp. There is considerable concern of potential health hazards associated with the release of this substance into the environment. Animals exposed to a single, oral dose of TCDD typically begin to exhibit reduced food intake after two to three days that is associated with progressive weight loss, and mobilization of adipose tissue stores $(5,7,9)$. Furthermore, loss of appetite and decreased body weight have been reported in humans exposed to TCDD in the work place $(16,17$, 19). The TCDD induced anorexia may be due to a specific effect on the regulatory systems of food intake. The regulation of food intake and appetite is an extremely complex process which involves numerous peptides and hormones $(10,12)$. The hypothalamus has been considered to play a central role in this regulation (11). The hypothalamus maintains the nutritional homeostasis of the organism by activating or deactivating the food-seeking behaviors of the animal. It is known that endogenous opioid peptides (EOP) such as $\beta E$ play a physiological role in appetite and regulation of food intake $(2,6,13)$. Different areas of the hypothalamus have been associated with EOP mediated modula- tion of eating. The hypothalamus, like the pituitary, contains proopiomelanocortin (POMC), the precursor molecule for the opioid $\beta E$. $\beta E$, a by-product of the precursor POMC peptide, is present in high concentrations in the hypothalamus (10). It has been suggested that decreased hypothalamic $\beta E$ concentration is a mechanism for the down regulation of feeding behavior to conserve energy during periodic food shortages (4). It has also been shown that opioid receptor receptor blockade (i.e., antagonist binding) reduces food intake and body weight $(2,6,13)$. The possibility exists that TCDD intoxication may affect levels of EOP and their receptors, which could have a profound impact on the regulation of feeding behavior. Thus this study was performed to assess if hypothalamic $\beta E$ and its brain receptor (mu) are associated with TCDD-induced anorexia and body weight decline.

\section{METHOD}

TCDD ( $50 \mu \mathrm{g} / \mathrm{kg}$ ) was administered in a single, oral dose to adult, male Sprague-Dawley rats $(200-220 \mathrm{~g})$. This is a dose less than the reported $L D_{50}$ for adult, male Sprague-Dawley rats (60

${ }^{1}$ Requests for reprints should be addressed to Walter N. Piper at his current address: Toxicology Program, University of Michigan, 109 S. Observatory, 6108 SPH-II, Ann Arbor, MI 48109-2029. 
$\mu \mathrm{g} / \mathrm{kg}$ ) (1). However, it is important to note that in this strain of rats in our laboratory, a $50 \mu \mathrm{g} / \mathrm{kg}$ oral dose of TCDD has never produced deaths at three weeks of exposure. Acetone-corn oil $(1: 2 ; 3.8 \mathrm{ml} / \mathrm{kg})$, served as the control vehicle. Rats were permitted food and water ad lib. A weight-matched group of rats had their food restricted. At early time periods of 1-3 days, it is not practical to employ paired-feeding studies since they comprise providing food amounts consumed the previous day. Therefore, food-restricted rats were given the amount of food consumed from previous experiments in which 30 rats of the same weight range were administered the same dose of TCDD $(50 \mu \mathrm{g} / \mathrm{kg}$; single oral dose). These restricted amounts of food were 3,6 , and 6 grams at days 1,2 , and 3 , respectively. This was done to confirm that the effects of treatment were due to TCDD and not to a decrease in food intake. All animals were maintained on a controlled light cycle (6:00 a.m. lights on; 6:00 p.m. lights off), with restricted access to minimize environmental disturbances to the rats for the duration of the experiment. Rats were killed (9:00 a.m.) by decapitation, their brains rapidly removed, and hypothalamic blocks dissected with the following limits: cuts were made posterior to the optic chiasm, anterior to the mamillary bodies and through the lateral hypothalamic sulci, with a depth of $2 \mathrm{~mm}$. The hypothalami were frozen in liquid nitrogen, lyophilized and extracted in $0.1 \mathrm{~N} \mathrm{HCl}$ (15). Hypothalamic extracts were analyzed for $\beta E$ content using a radioimmunoassay kit obtained from INCSTAR (Stillwater, MN). The sensitivity of the assay was $10 \mathrm{pg} / \mathrm{ml}$. The data were statistically evaluated by analysis of variance $(p<0.05)$ with differences between means evaluated by Tukey's Test $(p<0.05)$.

Membranes from rat cerebrum were prepared and mu opioid receptor binding assays were performed (3). The binding-assay reaction consisted of $190 \mu$ l of membrane suspension (approximately $0.6 \mathrm{mg} / \mathrm{ml}$ protein), $20 \mu \mathrm{l}$ of distilled $\mathrm{H}_{2} \mathrm{O}, 25 \mu \mathrm{l}$ of either distilled $\mathrm{H}_{2} \mathrm{O}$ or excess $(2 \mu \mathrm{M})$ [D-Ala ${ }^{2}$, NMe-Phe ${ }^{4}$, Glyol]-Enkephalin (DAGO), and $25 \mu \mathrm{l}$ of the appropriate concentration of ${ }^{3} \mathrm{H}$-DAGO $(0.125-10 \mathrm{nM})$ in $8 \mathrm{ml}$ polypropylene tubes. The final volume of the assay was $260 \mu \mathrm{l}$. Specific binding of the radioligand is defined as the difference between binding in the absence and presence of an appropriate excess of DAGO. After incubation for 80 minutes at $25^{\circ} \mathrm{C}$ (reflecting binding equilibrium), the samples were filtered through glass fiber filters (GF/ C). The filtered samples were washed with ice cold $50 \mathrm{mM}$ Tris- $\mathrm{HCl}, \mathrm{pH} 7.4$, and placed into polyethylene counting vials. After addition of $1 \mathrm{ml}$ absolute ethanol followed by $10 \mathrm{ml}$ of biodegradable scintillation fluid, vials were subjected to liquid scintillation counting. Receptor number $\left(B_{\max }\right)$ and binding affinity $\left(K_{d}\right)$ were determined by Scatchard analysis (18). Protein concentration was determined by the method of Lowry and coworkers (8). The data were statistically evaluated by analysis of variance $(p<0.05)$ with differences between means evaluated by Tukey's Test $(p<0.05)$.

\section{RESULTS}

Body weights did not differ at days 1 and 2 for control, food-restricted control or TCDD groups. At day 3, body weights of TCDD-treated animals (196 \pm 5$)$ were significantly lower than control $(223 \pm 4)$ or food-restricted control $(220 \pm 6)$ groups, which did not differ from each other. Rat hypothalamic $\beta E$ concentrations were initially found to be significantly higher than controls at day 1 , and then were significantly depressed at days 2 and 3 following the administration of TCDD (Fig. 1). Hypothalamic $\beta E$ levels were increased to $166 \%$ of controls on day I; whereas at days 2 and 3 hypothalamic $\beta E$ concentrations were depressed to $39 \%$ and $49 \%$ of control values, respectively. Restricting the food intake did not change hypothalamic $\beta E$ con-

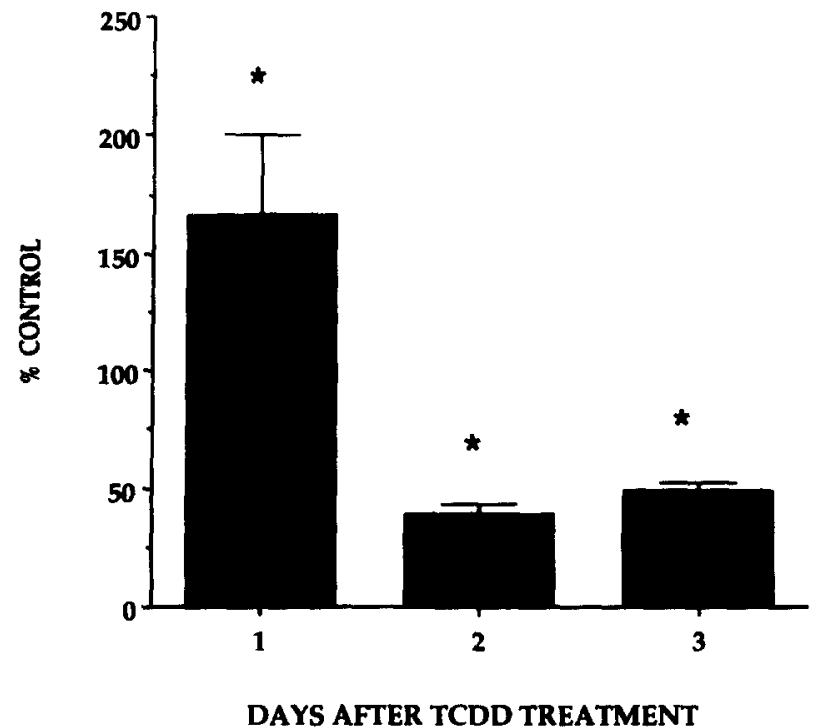

FIG. 1. Rat hypothalamic $\beta E$ concentrations after exposure to TCDD. Rats received a single, oral dose of $50 \mu \mathrm{g} / \mathrm{kg}$ at day 0 . Values represent the mean $\pm S E M$ for four rats. $\beta E$ was measured by radioimmunoassay. Mean control values were $6.0 \mathrm{pg} \beta E /$ hypothalamus $\pm 1.5,12.4 \pm 1.6$ and $11.6 \pm 1.9$ for days 1,2 and 3 , respectively. Mean $\beta E$ concentrations following three days of food restriction were $12.3 \pm 1.7 \mathrm{pg} \beta E /$ hypothalamus. Asterisks denote significant difference $(p<0.05)$ between control and TCDD-treated rats.

centration at day $3(11.6 \pm 1.9$ and $12.3 \pm 1.7$ for control and food-restricted control groups, respectively: $p>0.05$ ). The receptor for $\beta E(\mathrm{mu})$ was then analyzed after TCDD treatment by Scatchard analysis. Brain mu receptor number $\left(B_{\max }\right)$ at day 3 was increased $60 \%$ over control values following administration of TCDD, but the binding affinity $\left(\mathrm{K}_{d}\right)$ of the mu receptor remained unchanged. Restricting the food intake did not change either brain mu receptor number or affinity (Table 1). Figure 2 shows a typical Scatchard plot of the specific binding of DAGO in control and TCDD-treated rats.

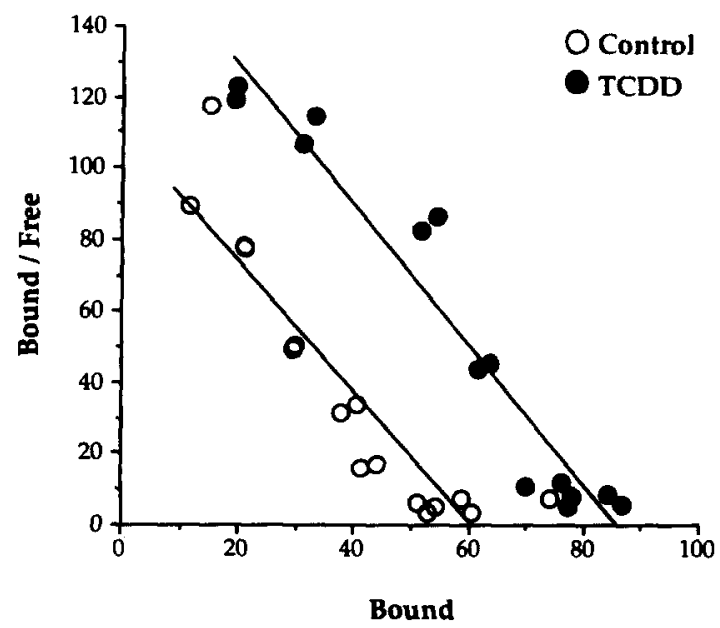

FIG. 2. Scatchard transformation of $\left[{ }^{3} H\right] D A G O$ binding to control and TCDD-treated rat membranes. A typical experiment is shown; data from several experiments are summarized in Table 1 . The $r$ value was greater than .940 in all cases. 
TABLE 1

EFFECT OF TCDD ON RAT BRAIN MU OPIOID RECEPTORS

\begin{tabular}{llc}
\hline Treatment & $\begin{array}{c}\mathrm{B}_{\max } \\
(\mathrm{fmol} / \mathrm{mg})\end{array}$ & $\begin{array}{c}\mathrm{K}_{\mathrm{d}} \\
(\mathrm{nM})\end{array}$ \\
\hline Control & $53.3 \pm 7.3$ & $0.40 \pm 0.08$ \\
TCDD & $85.6 \pm 3.5^{*}$ & $0.50 \pm 0.05$ \\
Food Restricted & $52.0 \pm 5.3$ & $0.43 \pm 0.05$
\end{tabular}

Rats were treated with a single, oral dose of TCDD (50 $\mu \mathrm{g} / \mathrm{kg})$ and sacrificed at day 3 .

Values represent the mean \pm SEM for 4 rats.

*Denotes a significant difference $(p<0.05)$ between control and treated rats.

\section{DISCUSSION}

It is known that EOP are involved in the highly complex chain of events forming the biochemical basis of appetite and regulation of food intake. It has been suggested that a decrease in hypothalamic $\beta E$ levels is a mechanism for the down regulation of feeding behavior to conserve energy during periodic food shortages (4). It has also been shown that opioid receptor antagonists reduce food intake and body weight by displacement of opioid peptides at their binding site $(2,6,13)$. A characteristic of antagonist treatment is an upregulation of the opioid receptor $(14,20-22)$. Since the present study shows that TCDD causes an increase in receptor number, it appears that TCDD may be acting as an opioid antagonist. This change, along with the decrease in hypothalamic $\beta E$ levels, is coincident with the time interval that rats begin to exhibit reduced-food intake and progressive weight loss after exposure to TCDD. In addition, rats receiving an amount of food comparable to that consumed by TCDD-treated rats had $\beta E$ and mu receptor numbers similar to control rats. These results demonstrate discrete effects of TCDD which are not due to a decrease in food consumption. Thus our data suggest that a mechanism by which TCDD exerts its effects on rat appetite regulation is two fold; first, by decreasing hypothalamic $\beta E$ levels and second, by displacement of $\beta E$ at the opioid receptor site. These data do not rule out the possible participation of biogenic amines, other neuropeptides or hormones in TCDD-induced hypophagia.

\section{Conclusion}

The present findings suggest that EOP may contribute to the mechanisms by which TCDD exposure leads to depressed food intake and progressive weight loss. This knowledge may ultimately lead to information enabling treatment regimens to restore feeding and correct body weight loss associated with exposure to this toxicant.

\section{ACKNOWLEDGEMENT}

This research was supported in part by T32 ES-07062.

\section{REFERENCES}

1. Beatty, P. W.; Vaughn, W. K.; Neal, R. A. Effect of alteration of rat hepatic mixed-function oxidase (MFO) activity on the toxicity of 2,3,7,8-tetrachlorodibenzo-p-dioxin (TCDD). Toxicol. Appl. Pharmacol. 45:513-519; 1978.

2. Cooper, S. J.; Jackson, A.; Kirkham, T. C.; Turkish, S. Endorphins, opiates and food intake, In: Rodgers, R. J.; Cooper S. J., eds. Endorphins, opiates and behavioral processes. New York: John Wiley and Sons; 1988:143-186.

3. Fishel, S. V.; Medzihradsky, F. Scatchard analysis of opiate receptor binding. Mol. Pharmacol. 20:269-279; 1981.

4. Gambert, S. R.; Garthwaite, T. L.; Pontzer, C. H.; Hagen, T. C. Fasting associated with decrease in hypothalamic $\beta$-endorphin. Science $210: 1271-1272 ; 1980$.

5. Gasiewicz, T. A.; Holscher, M. A.; Neal, R. A. The effect of total parenteral nutrition on the toxicity of $2,3,7,8$-tetrachlorodibenzo-pdioxin in the rat. Toxicol. Appl. Pharmacol. 54:469-488; 1980.

6. Gosnell, B. A. Central structures involved in opioid-induced feeding. Fed. Proc. 46:163-167; 1987.

7. Harris, M. W.; Moore, J. A.; Vos, J. G.; Gupta, B. N. General biological effects of TCDD in laboratory animals. Environ. Health Perspect. Exp. Issue 5:101-109; 1973.

8. Lowry, O. H.; Rosebrough, N. A.; Farr, A. L.; Randall, R. J. Protein measurement with the Folin phenol reagent. J. Biol. Chem. 193:265-275; 1951.

9. McConnell, E. E.; Moore, J. A.; Dalgard, D. W. Toxicity of 2,3,7,8-tetrachlorodibenzo-p-dioxin in rhesus monkeys (Macaca mulata) following a single oral dose. Toxicol. Appl. Pharmacol. 45: 175-187; 1978.

10. Morely, J. E. Neuropeptide regulation of appetite and weight. Endocr. Rev. 8:256-287; 1987.

11. Morely, J. E. The neuroendocrine control of appetite: The role of the endogenous opiates, cholecystokinin, TRH, gamma-amino- butyric-acid and the diazepam receptor. Life Sci. 27:355-368; 1980.

12. Morely, J. E.; Levine, A. S. The pharmacology of eating behavior. Annu. Rev. Pharmacol. Toxicol. 25:127-146; 1985.

13. Morley, J. E.; Levine, A. S.; Yim, G. K.; Lowy, M. T. Opiate modulation of appetite. Neurosci. Biobehav. Rev. 7:281-305; 1983.

14. Morris, B. J.; Millan, M. J.; Herz, A. Antagonist-induced opioid receptor up-regulation, II. Regionally specific modulation of mu, delta and kappa binding sites in rat brain revealed by quantitative autoradiography. J. Pharmacol. Exp. Ther. 247:729-736; 1988.

15. Procknor, M. PhD. Dissertation, Texas A\&M University; 1986.

16. Reggiani, G. Toxicology of 2,3,7,8-tetrachlorodibenzo-p-dioxin(TCDD): Short review of its formation, occurrence, toxicology, $\mathrm{ki}-$ netics, discussing human health effects, safety measures, and disposal. Regul. Toxicol. Pharmacol. 1:211-243; 1981.

17. Reggiani, G. Toxicology of TCDD and related compounds: Observations in man, In: Hutzinger, $O$., ed. Chlorinated dioxins and related compounds: Impact on the environment. New York: Pergamon Press; 1980:463.

18. Scatchard, G. The attraction of proteins for small molecules and ions. Ann. NY Acad. Sci. 51:660-672; 1949.

19. Scientific Review Committee of the American Academy of Clinical Toxicology. Clin. Toxicol. 23:191-204; 1985.

20. Tempel, A.; Gardner, E. L.; Zukin, R. S. Neurochemical and functional correlates of naltrexone-induced opiate receptor up-regulation. J. Pharmacol. Exp. Ther. 232:439-444; 1985.

21. Yoburn, B. C.; Sierra, V.; Lutfy, K. Chronic opioid antagonist treatment: Assessment of receptor upregulation. Eur. J. Pharmacol. 170:193-200;1989.

22. Zukin, R. S.; Sugerman, J. R.; Fitz-Syage, M. L.; Gardner, E. L.; Zukin, S. R.; Gintzler, A. R. Naltrexone-induced opiate receptor supersensitivity. Brain Res. 245:285-292; 1982. 